\title{
Nipah Virus- A Rapidly Emerging Zoonoses: A Mini Review
}

\author{
Sidra Zafar*, Zareen Fatima, Muneeza Ekram \\ Department of Microbiology, Jinnah University for Women, Karachi, Pakistan.
}

\begin{abstract}
Nipah virus is one of the deadliest viruses of Paramyxoviridae family, of the order Mononegavirales. The virus is harbored by Pteropus fruit bats and transmitted to pigs via partially eaten fruits or direct exposure to infectious bat secretions. Viral determinants that contribute to Nipah virus infection include $\mathrm{V}$ and $\mathrm{W}$ proteins where $\mathrm{W}$ protein plays a more prominent role. It is Known for causing severe and rapidly progressive encephalitis and thus classified among BSL-4 organisms due to its high mortality rate and lack of vaccines and drugs. Due to wide spread primary host the potential for outbreaks to occur in new regions remains significant and suggests a serious potential for larger epidemics in the future. Therefore proper management and preventive measures are needed to be implemented by health care workers, as well as at the government level.
\end{abstract}

Keywords: Viral infection, Zoonoses, Fruit bats, Transmission, Nipah virus, BSL-4 organism, Paramyxovirus.

\section{INTRODUCTION}

Among the deadliest viruses of the order Mononegavirales, nipah virus belongs to the Paramyxoviridae family of the genus Henipavirus [1]. It is highly pathogenic causative agent of respiratory and encephalitic disease in Southeast Asia [2]. Structure of virus consist of an envelope made of filamentous nucleocapsid made of major structural proteins i.e. fusion protein, glycoprotein, phosphoprotein, matrix protein and large protein (RNA polymerase). However, the genome of the virus is single stranded negative sense RNA which is a hallmark of the Paramyxoviridae family [3, 4]. Pteropus fruit bat serves as a reservoir for the virus. Zoonotic transmission occurs directly or through an intermediate host, however the outbreak was the result of pig-to-human transmission and requires between 4 and 30 days of incubation period [2-5]. Cases with the disease presents abrupt onset of fever, headache, dizziness, vomiting, respiratory and neurological illness including altered consciousness, encephalitis, hypotonia, areflexia etc. [5, 6]. The virus is well known for its outbreak in late 1998 and early 1999 in Malaysia and Singapore which resulted in 276 human cases with 106 deaths [2, 3, $5,7]$. The autopsy of fatal cases showed that CNS seemed to be a major target for the pathogen where it was found to be forming syncytium $[3,8,9]$.

\section{PATHOGENICITY}

Alpha/beta interferon constitutes STAT proteins (STAT1/STAT2 along with IFN regulatory factor-IRF9). It is part of innate immune system that provides cell protection against viral infections. ISGF3 transcription complex mediates the biological effect of Alpha/beta interferon [10, 11]. Thus IFN-induced, ISGF3-mediated transcription provides protection against broad range of viral infection, however most viruses have evolved to evade the INF induced protec-

*Address correspondence to this author at the Department of Microbiology Jinnah University for Women, Karachi, Pakistan.

E-mails: sid_78@live.com, sidrazfr@gmail.com tion $[12,13]$. Viruses belonging to the Paramyxoviridae family causes infection by evading ISGF3 signals that are responsible for targeting STAT proteins in order to activate the Alpha/beta interferon [14]. Hence paramyxovirus-encoded V protein interacts with STAT proteins thereby blocking the interferons. V proteins were also observed to be responsible for various virulence activities such as blocking apoptosis, cell cycle arrest, IRF3 suppression and other protein-protein interactions [15-20]. Therefore $\mathrm{V}$ protein is a virulence and pathogenicity determining factor of paramyxovirus family [14]. $\mathrm{V}$ and $\mathrm{W}$ proteins both are responsible for bypassing the immune system but $\mathrm{W}$ protein is considered more potent as compare to $\mathrm{V}$ proteins. V proteins of nipah virus (Niv) inhibit the antiviral activity of RIG-I and MDA5 by phosphatase PP1 and STAT through direct sequestration hence responsible for blocking only Inhibitor of $\mathrm{kB}$ kinase e (IKKe) signaling pathway [21-26]. Whereas Niv W proteins causes infection by impairing the function of IFN transcription factor 3 , hence blocking Toll-like receptor 3 and Inhibitor of $\mathrm{kB}$ kinase e (IKKe) signaling pathways. It was also observed to be responsible in the suppression of IFN-b and IFN-stimulated gene 54 (ISG54) promoters in HEK 293T cells [25, 26].

Furthermore, UBXN1 A host protein, interacts with NiV V and thus increases the level of UBXN1 protein by suppressing its proteolysis and suppresses the interferon activation [27]. Therefore Viruses that are missing $\mathrm{V}$ proteins are more prone to immune response both in vitro and in vivo and are non-lethal. Delay or alteration in the disease course was observed with viruses lacking $\mathrm{W}$ proteins. Such viruses also show reduced respiratory and elevated neurological disease [28].

\section{EFFORTS IN VACCINE AND DRUG DEVELOPMENT}

Nipah virus is classified among BSL- 4 pathogens due to high mortalities in humans and its human to human transmission as well as absence of vaccine or specific antiviral treatment. 
Considering the pathogenesis and high mortality rate there are no vaccine available for human use. Recently a subunit $\mathrm{HeV}$ vaccine has been approved for animal use in Australia [29-31]. Also a viral envelop protein targeting monoclonal antibodies has been studied for animal and human use as post-exposure prophylaxis but the efficacy of treatment to human disease is yet to be studied [30-32]. Ribavirin is a broad spectrum antiviral drug used primarily for the treatment of hepatitis $\mathrm{C}$ and viral hemorrhage. The drug was reported to show effectiveness in Malaysian outbreak with $36 \%$ reduction in mortality [33] but also reported by others for its ineffectiveness against henipa virus infection [34-37]. Lately an analogue targeting RNA polymerase dependent on viral RNA has been developed named favipiravir. At present it is in use for influenza $[38,39]$ and has shown efficacy against Niv infected hamster models [40]. Furthermore the analogue has completed phase 2 trials as showed promising results against Ebola Virus infection in reducing the mortality rate [41].

Most of the vaccines for viral infection are in early stages of development. Using viral components and their expression in various viral vector for vaccine preparation is an attractive approach [42, 43]. Although currently there are no licensed vaccines available for the Niv infection but there are evidences that suggests that effective vaccine is attainable. Vaccines usually targets viruses having an incubation period of at least 5-7 days whereas shorter incubation period leads to unsuccessful vaccine development, therefore, incubation period of Niv is greater than 5-7 day threshold hence a potential vaccine is feasible [2]. Glycoprotein and Fusion outer membrane proteins are used for the development of vaccines to induce immune response in following animal models; African green monkeys (AGMs) hamsters, pigs, cats and ferrets etc. [44-50]. Vaccines using $\mathrm{G}$ proteins and Alhydroge ${ }^{\circledR}$ and $\mathrm{CpG}$ oligodeoxynucleotide as an adjuvant exhibit potency against viral infected animal models. Equivac $\mathrm{HeV}^{\circledR}$ is an advanced vaccine of this category [51]. However, due to life threatening nature of virus, preparation of live attenuated vaccine with no possibility of reversion is a difficult task [28, 52].

\section{LABORATORY DIAGNOSIS AND PREVENTION}

For laboratory diagnosis of viral infection following methods are mainly used; serology, histopathology, immunohistochemistry, electron microscopy, polymerase chain reaction (PCR), and virus isolation. ELISA, imunohistochemistry and serology are safer methods as they don't intensify the viral infection and can be used as methods for initial screening purpose [53]. Due to limited treatment options for Nipha virus, focus on preventions of viral infections is significant. Following preventive strategies should be of main focus; farm animals should be kept far away from bat reservoirs, partially eaten bat fruits, overcrowding of farm with animals should be avoided, farms should be designed in areas that do not attract bats [54]. Execution of standard precaution and donning of proper personal protective equipment (PPE) by healthcare workers while handling, caring and visiting suspected or confirmed NiV infection patient is important [55-57].

\section{CONCLUSION}

Nipah virus is rapidly emerging zoonotic virus that is classified among BSL-4 organisms due to its high mortality and absence of treatment. In recent year's outbreak of viral infection continue to occur in India and other Asian countries and due to widespread primary host, the potential for outbreaks to occur in new regions remains significant and suggests a serious potential for larger epidemics in the future. Prevention of viral infection is difficult in developing countries as it's a rare infection compared to other medical health threats faced by the people in low income areas. Improved understanding of the mechanism of zoonotic transmission from bats to humans might facilitate establish possible approaches to stop future introductions of the virus into the human population. The treatment currently used is just supportive and to develop a stable, vigorous and affordable drug or vaccine for the infection is one of the major challenges in order to limit the future epidemics, additionally restriction of activities that increases the interaction between animals, people and fruit bats could help prevent spread of infection.

\section{CONFLICT OF INTEREST}

Declared none.

\section{ACKNOWLEDGEMENTS}

Declared none.

\section{REFERENCES}

[1] Amarasinghe GK, Bào Y, Basler CF, et al. Taxonomy of the order mononegavirales: Update 2017. Arch Virol 2017; 162(8): 2493-504. DOI: 10.1007/s00705-017-3311-7

[2] Kaslow DC. Biological feasibility of developing prophylactic vaccines for viral pathogens: Incubation period as a critical parameter. Hum Vaccines 2007; 3(1): 1-7.

DOI: $10.4161 /$ hv.3.1.3519

[3] Chua KB, Bellini WJ, Rota PA, et al. Nipah virus: A recently emergent deadly paramyxovirus. Science 2000; 288(5470): 1432-5. DOI: 10.1126/science.288.5470.1432

[4] Wang LF, Harcourt BH, Yu M, et al. Molecular biology of Hendra and Nipah viruses. Microbe Infect 2001; 3(4): 279-87. DOI: $10.1016 / \mathrm{S} 1286-4579(01) 01381-8$

[5] Hossain MJ, Gurley ES, Montgomery JM, et al. Clinical presentation of Nipah virus infection in Bangladesh. Clin Infect Dis 2008; 46(7): 977-84. DOI: 10.1086/529147

[6] Halpin K, Hyatt AD, Fogarty R, et al. Pteropid bats are confirmed as the reservoir hosts of henipaviruses: A comprehensive experimental study of virus transmission. Am J Trop 
Med Hyg 2011; 85(5): 946-51.

DOI: 10.4269 /ajtmh.2011.10-0567

[7] Nor MM, Gan CH, Ong BL. Nipah virus infection of pigs in peninsular Malaysia. Rev Sci Tech 2000; 19(1): 160-5. DOI: $10.20506 /$ rst.19.1.1202

[8] Paton NI, Leo YS, Zaki SR, et al. Outbreak of Nipah-virus infection among abattoir workers in Singapore. Lancet 1999; 354(9186): 1253-6. DOI: 10.1016/S0140-6736(99)04379-2

[9] Chua KB, Goh KJ, Wong KT, et al. Fatal encephalitis due to Nipah virus among pig-farmers in Malaysia. Lancet 1999; 354(9186): 1257-9. DOI: 10.1016/S0140-6736(99)04299-3

[10] Aaronson DS, Horvath CM. A road map for those who don't know JAK-STAT. Science 2002; 296(5573): 1653-5. DOI: $10.1126 /$ science. 1071545

[11] Levy DE, Darnell Jr JE. Signaling: Stats: Transcriptional control and biological impact. Nat Rev Mol Cell Biol 2002; 3(9): 651. DOI: 10.1038/nrm909

[12] Levy DE, Garcia-Sastre A. The virus battles: IFN induction of the antiviral state and mechanisms of viral evasion. Cytokine Growth Factor Rev 2001; 12(2-3): 143-56.

DOI: 10.1016/S1359-6101(00)00027-7

[13] Samuel CE. Antiviral actions of interferons. Clin Microbiol Rev 2001; 14(4): 778-809.

DOI: $10.1128 / C M R .14 .4 .778-809.2001$

[14] Didcock L, Young DF, Goodbourn S, Randall RE. Sendai virus and simian virus 5 block activation of interferon-responsive genes: Importance for virus pathogenesis. J Virol 1999; 73(4): 3125-33.

[15] He B, Paterson RG, Stock N, et al. Recovery of paramyxovirus simian virus 5 with a $\mathrm{V}$ protein lacking the conserved cysteine-rich domain: The multifunctional $\mathrm{V}$ protein blocks both interferon- $\beta$ induction and interferon signaling. Virology 2002; 303(1): 15-32. DOI: 10.1006/viro.2002.1738

[16] Kawano M, Kaito M, Kozuka Y, et al. Recovery of infectious human parainfluenza type 2 virus from cDNA clones and properties of the defective virus without $\mathrm{V}$-specific cysteine-rich domain. Virology 2001; 284(1): 99-112. DOI: $10.1006 /$ viro.2001.0864

[17] Lin GY, Lamb RA. The paramyxovirus simian virus $5 \mathrm{~V}$ protein slows progression of the cell cycle. J Virol 2000; 74(19): 9152-66. DOI: 10.1128/JVI.74.19.9152-9166.2000

[18] Lin GY, Paterson RG, Richardson CD, Lamb RA. The V protein of the paramyxovirus SV5 interacts with damage-specific DNA binding protein. Virology 1998; 249(1): 189-200. DOI: $10.1006 /$ viro.1998.9317

[19] Paterson RG, Leser GP, Shaughnessy MA, Lamb RA. The paramyxovirus SV5 V protein binds two atoms of zinc and is a structural component of virions. Virology 1995; 208(1):
121-31. DOI: 10.1006/viro.1995.1135

[20] Poole E, He B, Lamb RA, Randall RE, Goodbourn S. The V proteins of simian virus 5 and other paramyxoviruses inhibit induction of interferon- $\beta$. Virology 2002; 303(1): 33-46.

DOI: $10.1006 /$ viro.2002.1737

[21] Childs K, Randall R, Goodbourn S. Paramyxovirus V proteins interact with the RNA Helicase LGP2 to inhibit RIG-I-dependent interferon induction. J Virol 2012; 86(7): 3411-21.

DOI: 10.1128/JVI.06405-11

[22] Childs K, Stock N, Ross C, et al. Mda-5, but not RIG-I, is a common target for paramyxovirus V proteins. Virology 2007; 359(1): 190-200. DOI: 10.1016/j.virol.2006.09.023

[23] Davis ME, Wang MK, Rennick LJ, et al. Antagonism of the phosphatase PP1 by the measles virus $\mathrm{V}$ protein is required for innate immune escape of MDA5. Cell Host Microbe 2014; 16(1): 19-30. DOI: 10.1016/j.chom.2014.06.007

[24] Rodriguez JJ, Parisien JP, Horvath CM. Nipah virus V protein evades alpha and gamma interferons by preventing STAT1 and STAT2 activation and nuclear accumulation. J Virol 2002; 76(22): 11476-83.

DOI: $10.1128 / J V I .76 .22 .11476-11483.2002$

[25] Shaw ML, Cardenas WB, Zamarin D, Palese P, Basler CF. Nuclear localization of the Nipah virus $\mathrm{W}$ protein allows for inhibition of both virus-and toll-like receptor 3-triggered signaling pathways. J Virol 2005; 79(10): 6078-88.

DOI: $10.1128 / J V I .79 .10 .6078-6088.2005$

[26] Ciancanelli MJ, Volchkova VA, Shaw ML, Volchkov VE, Basler CF. Nipah virus sequesters inactive STAT1 in the nucleus via a $\mathrm{P}$ gene-encoded mechanism. J Virol 2009; 83(16): 7828-41. DOI: 10.1128/JVI.02610-08

[27] Uchida S, Horie R, Sato H, Kai C, Yoneda M. Possible role of the Nipah virus $\mathrm{V}$ protein in the regulation of the interferon beta induction by interacting with UBX domain-containing protein1. Sci Rep 2018; 8(1): 7682.

DOI: $10.1038 / \mathrm{s} 41598-018-25815-9$

[28] Satterfield BA, Cross RW, Fenton KA, et al. The immunomodulating $\mathrm{V}$ and $\mathrm{W}$ proteins of Nipah virus determine disease course. Nat Commun 2015; 6: 7483.

DOI: $10.1038 /$ ncomms 8483

[29] Mire CE, Geisbert JB, Agans KN, et al. A recombinant Hendra virus $G$ glycoprotein subunit vaccine protects nonhuman primates against Hendra virus challenge. J Virol 2014; 88(9): 4624-31. DOI: 10.1128/JVI.00005-14

[30] Broder CC. Passive immunization and active vaccination against Hendra and Nipah viruses. Dev Biol (Basel) 2013; 135: 125-38. DOI: $10.1159 / 000171017$

[31] Cartwright, D. Hendra virus vaccine trial reveals no ill-effects. 2016; Available at: https://www.smh.com.au/nation- 
a $1 /$ q u e e n s 1 a n d/he nd r a - virus - va c cine-trial-reveals-no-illeffects-20160628-gpt9nk.html [Updated June 28, 2016].

[32] Geisbert TW, Mire CE, Geisbert JB, et al. Therapeutic treatment of Nipah virus infection in nonhuman primates with a neutralizing human monoclonal antibody. Sci Transl Med 2014; 6(242): 242ra82. DOI: 10.1126/scitranslmed.3008929

[33] Chong HT, Kamarulzaman A, Tan CT, et al. Treatment of acute Nipah encephalitis with ribavirin. J Am Neurol Assoc Child Neurol Soc 2001; 49(6): 810-3. DOI: 10.1002/ana.1062

[34] Pallister J, Middleton D, Crameri G, et al. Chloroquine administration does not prevent Nipah virus infection and disease in ferrets. J Virol 2009; 83(22): 11979-82.

DOI: $10.1128 /$ JVI.01847-09

[35] Rockx B, Bossart KN, Feldmann F, et al. A novel model of lethal Hendra virus infection in African green monkeys and the effectiveness of ribavirin treatment. J Virol 2010; 84(19): 9831-9. DOI: 10.1128/JVI.01163-10

[36] Freiberg AN, Worthy MN, Lee B, Holbrook MR. Combined chloroquine and ribavirin treatment does not prevent death in a hamster model of Nipah and Hendra virus infection. J Gen Virol 2010; 91(3): 765-72. DOI: 10.1099/vir.0.017269-0

[37] Georges-Courbot MC, Contamin H, Faure C, et al. Poly (I)-poly $(\mathrm{C} 12 \mathrm{U})$ but not ribavirin prevents death in a hamster model of Nipah virus infection. Antimicrob Agents Chemother 2006; 50(5): 1768-72.

DOI: 10.1128/AAC.50.5.1768-1772.2006

[38] Furuta Y, Gowen BB, Takahashi K, Shiraki K, Smee DF, Barnard DL. Favipiravir (T-705), a novel viral RNA polymerase inhibitor. Antiviral Res 2013; 100(2): 446-54. DOI: 10.1016/j.antiviral.2013.09.015

[39] Furuta Y, Takahashi K, Fukuda Y, et al. In vitro and in vivo activities of anti-influenza virus compound T-705. Antimicrob Agents Chemother 2002; 46(4): 977-81.

DOI: $10.1128 /$ AAC.46.4.977-981.2002

[40] Dawes BE, Kalveram B, Ikegami T, et al. Favipiravir (T-705) protects against Nipah virus infection in the hamster model. Sci Rep 2018; 8(1): 7604. DOI: 10.1038/s41598-018-25780-3

[41] Sissoko D, Laouenan C, Folkesson E, et al. Experimental treatment with favipiravir for Ebola virus disease (the JIKI Trial): A historically controlled, single-arm proof-of-concept trial in Guinea. PLoS Med 2016; 13(3): e1001967.

DOI: 10.1371/journal.pmed.1002066

[42] Henao-Restrepo AM, Longini IM, Egger M, et al. Efficacy and effectiveness of an rVSV-vectored vaccine expressing Ebola surface glycoprotein: Interim results from the Guinea ring vaccination cluster-randomised trial. Lancet 2015; 386(9996): 857-66. DOI: 10.1016/S0140-6736(15)61117-5
[43] Middleton D, Pallister J, Klein R, et al. Hendra virus vaccine, a one health approach to protecting horse, human, and environmental health. Emerg Infect Dis 2014; 20(3): 372. DOI: $10.3201 /$ eid2003.131159

[44] DeBuysscher BL, Scott D, Marzi A, Prescott J, Feldmann H. Single-dose live-attenuated Nipah virus vaccines confer complete protection by eliciting antibodies directed against surface glycoproteins. Vaccine 2014; 32(22): 2637-44.

DOI: $10.1016 /$ j.vaccine.2014.02.087

[45] Lo MK, Bird BH, Chattopadhyay A, et al. Single-dose replication-defective VSV-based Nipah virus vaccines provide protection from lethal challenge in Syrian hamsters. Antiviral Res 2014; 101: 26-9. DOI: 10.1016/j.antiviral.2013.10.012

[46] McEachern JA, Bingham J, Crameri G, et al. A recombinant subunit vaccine formulation protects against lethal Nipah virus challenge in cats. Vaccine 2008; 26(31): 3842-52.

DOI: $10.1016 /$ j.vaccine.2008.05.016

[47] Mire CE, Versteeg KM, Cross RW, et al. Single injection recombinant vesicular stomatitis virus vaccines protect ferrets against lethal Nipah virus disease. Virol J 2013; 10(1): 353. DOI: $10.1186 / 1743-422 \mathrm{X}-10-353$

[48] Bossart KN, Rockx B, Feldmann F, et al. A Hendra virus G glycoprotein subunit vaccine protects African green monkeys from Nipah virus challenge. Sci Transl Med 2012; 4(146): 146ra107. DOI: 10.1126/scitranslmed.3004241

[49] Prescott J, DeBuysscher BL, Feldmann F, et al. Single-dose live-attenuated vesicular stomatitis virus-based vaccine protects African green monkeys from Nipah virus disease. Vaccine 2015; 33(24): 2823-9.

DOI: $10.1016 /$ j.vaccine.2015.03.089

[50] Weingartl HM, Berhane Y, Caswell JL, et al. Recombinant nipah virus vaccines protect pigs against challenge. J Virol 2006; 80(16): 7929-38. DOI: 10.1128/JVI.00263-06

[51] Satterfield BA, Dawes BE, Milligan GN. Status of vaccine research and development of vaccines for Nipah virus. Vaccine 2016; 34(26): 2971-5.

DOI: $10.1016 /$ j.vaccine.2015.12.075

[52] Yoneda M, Guillaume V, Sato H, et al. The nonstructural proteins of Nipah virus play a key role in pathogenicity in experimentally infected animals. PLoS One 2010; 5(9): e12709. DOI: 10.1371/journal.pone.0012709

[53] RAP Publication (FAO). Manual on the diagnosis of Nipah virus infection in animals. 2002; Available at: https://coin.f a o o o r g / c o i n - s t a t i c / c m s/m e dia/1/13170263993060/2002_01_high.pdf

[54] Nahar N, Mondal UK, Sultana R, et al. Piloting the use of indigenous methods to prevent Nipah virus infection by interrupting bats' access to date palm sap in Bangladesh. Health Promot Int 2012; 28(3): 378-86. 
DOI: $10.1093 /$ heapro/das020

[55] World Health Organization. Nipah virus infection. 2014; Available at: http://www.searo.who.int/entity/emerging_diseases/links/CDS_Nipah_Virus.pdf [Accessed June 2019].

[56] World Health Organization. Standard precautions in health care: Aide-memoire. 2014; Available at: https:/www.who.int/csr/resources/publications/EPR_AM2_E7.pdf [Accessed July 2019].
[57] World Health Organization. A brief guide to emerging infectious diseases and zoonoses. 2014; Available at: https://apps.who.int/iris/handle/10665/204722 [Accessed May 2018].

(C) 2019 National Journal of Health Sciences.

This is an open-access article. 